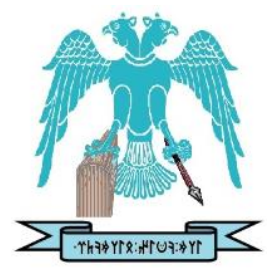

JOURNAL OF ENERGY SYSTEMS

$2021,5(1)$

\title{
Proton exchange membrane fuel cell fault and degradation detection using a coefficient of variance method
}

\author{
Sujit Sopan Barhate \\ Department of Technology, Savitribai Phule Pune University, Pune, India, 41107, sujitbarhate@ gmail.com \\ Rohini Mudhalwadkar \\ Instrumentation and Control Department, College of Engineering, Pune, India, 41105, rpm.instru@ coep.ac.in
}

\begin{abstract}
Proton exchange membrane fuel cell is a clean energy generator as it emits water as a by-product. The fuel cell has various applications in stationary power generation and transportation. However, there is a need to improve durability for transportation applications. Fuel cell durability is limited as its performance degrades over a period due to aging, and fault conditions. In this study, we have compared fuel cell performance by using a new cell, and an aged cell. Degradation due to aging is experimented with by using a membrane that was operated for more than 2000 hours. Fuel cell performance degrades around $90 \%$ due to aging. Moreover, experimentally faults were created to study the degradation of fuel cell performance. We created three faults in the fuel cell system: Water flooding, reactant gas starvation, and high operating temperature. Fuel cell performance observed more than $30 \%$ degradation during the fault conditions. Furthermore, the coefficient of variance technique is used to detect aging, and the fault condition.
\end{abstract}

Keywords: Coefficient of variance, Degradation, Fault, Fuel cell, PEM

Cite this paper as:

Barhate, S.S., Mudhalwadkar R., Proton exchange membrane fuel cell fault and degradation detection using a coefficient of variance method. Journal of Energy Systems 2021, 5(1), 20-34, DOI: $10.30521 /$ jes. 817879

(c) 2021 Published by peer-reviewed open access scientific journal, JES at DergiPark (https://dergipark.org.tr/en/pub/jes) 


\section{INTRODUCTION}

Pollution is a big concern for the world. Many countries have taken targets to reduce pollution. The pollution is mainly caused by burning fossil fuels. It generates Carbon dioxide $\left(\mathrm{CO}_{2}\right)$, which is contributing $77 \%$ of greenhouse gases (GHG). GHG emissions need to be reduced as they trap heat in the atmosphere. Fig. 1 shows the energy consumption by type of fuel. Around $80 \%$ of energy is generated by burning fossil fuels like petroleum, natural gas, and coal. Around $11 \%$ of energy is generated through renewable energy sources [1]. Renewable energy sources shall be increased to reduce the dependency of GHG emitting hydro-carbon based sources. Proton exchange membrane (PEM) fuel cell is one of the candidates for environment-friendly power generation. PEM fuel cell reacts Hydrogen with Oxygen to generate electricity, and emits water vapor. If Hydrogen is generated from renewable energy sources like solar, or wind then, it is the most environmentally friendly energy source. PEM fuel cell use as an energy source is increasing exponentially. Since volume is increasing, its cost is reducing. Fig. 2 shows the fuel cell volume increase, and cost reduction data [2].

\begin{tabular}{|lc}
\hline $\begin{array}{l}\text { biomass } \\
\text { renewable } \\
\text { heating, electricity, transportation }\end{array}$ & $5.0 \%$ \\
\hline $\begin{array}{l}\text { hydropower } \\
\text { renewable } \\
\text { electricity }\end{array}$ & $2.5 \%$ \\
\hline $\begin{array}{l}\text { wind } \\
\text { renewable } \\
\text { electricity }\end{array}$ & $2.7 \%$ \\
\hline $\begin{array}{l}\text { solar } \\
\text { renewable } \\
\text { heating, electricity }\end{array}$ & $1.0 \%$ \\
\hline $\begin{array}{l}\text { geothermal } \\
\text { renewable } \\
\text { heating, electricity }\end{array}$ & $0.2 \%$ \\
\hline
\end{tabular}

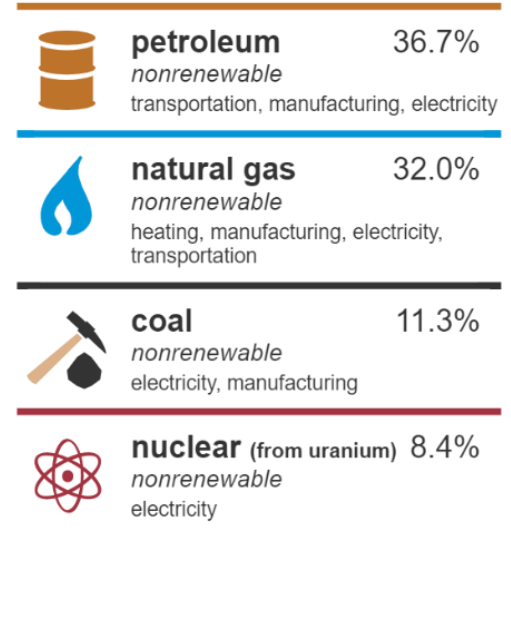

Figure 1. Energy consumption.

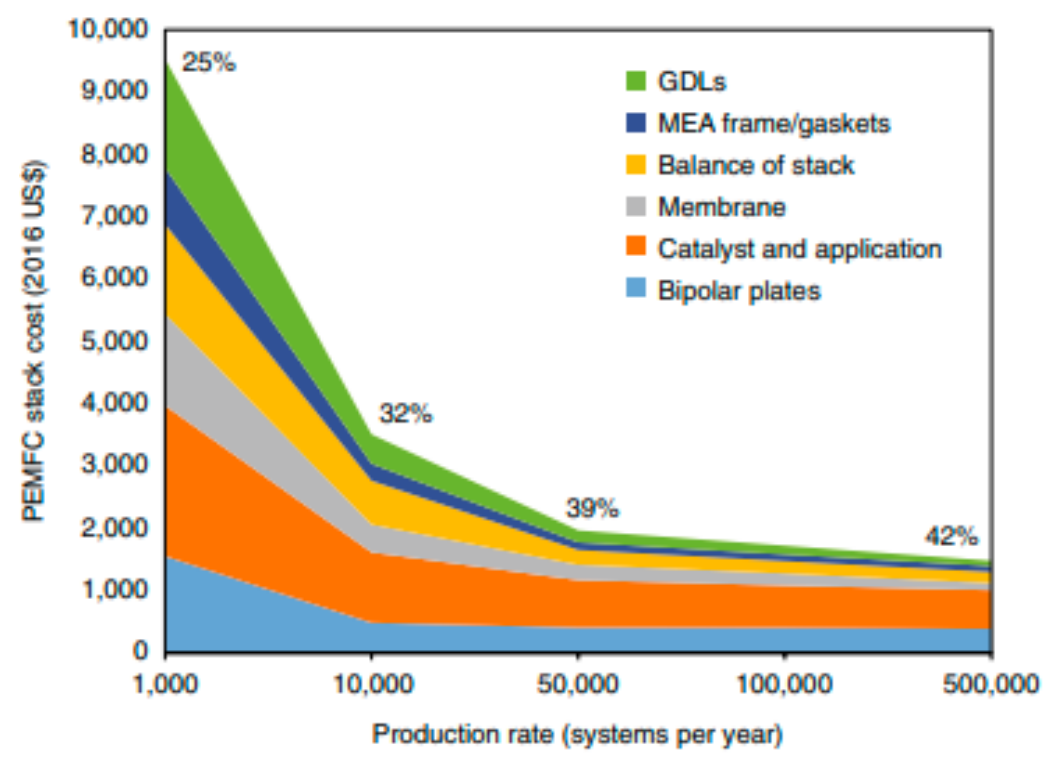

Figure 2. Drop in fuel cell price with increased volume. 
There are various other types of fuel cells like Solid Oxide fuel cell (SOFC), Direct Methanol fuel cell (DMFC), Molten Carbonate fuel cell (MCFC), Alkaline fuel cell (AFC), and Phosphorous Acid fuel cell (PAFC) $[3,4]$. Among these, the PEM fuel cell is better in terms of power density, efficiency, transient response, scalability, robustness, simple construction, lower operating temperature, and faster start-up time [5]. PEM fuel cell is an electrochemical device that generates electrical power by reacting Hydrogen with Oxygen. By-products of the reaction are water, and heat.

PEM fuel cell has applications in stationary as well as mobile power generations. Fuel cells are being used in automobiles, locomotive, and marine. A target of 5000 hours of durability is given by the US Department of Energy for transportation applications. However, around 4000 hours of durability is achieved so far [6]. Many researchers have studied the durability of the PEM fuel cell. They have calculated the remaining useful life of the fuel cell based on degradations. Artificial intelligence tools were used to predict durability [6]. Few used Auto-Regressive Moving Average (ARMA) models to predict fuel cell performance, and to calculate remaining useful life $[7,8,9]$. ARMA model was also used for the prognosis of fuel cell degradation [10]. Fuzzy logic [11], and adaptive neuro-fuzzy interference [12] are used for degradation, and prognosis respectively. A hybrid model is developed using wavelet analysis, a Genetic algorithm, and an Extreme learning machine to study degradation in fuel cells [13]. The model is experimentally validated in a fuel cell electric vehicle.

Fuel cell performance, life degrade due to faults in the fuel cell system, and mechanical degradation of the cell components are main concerns in that regard. Mechanical damages in the fuel cell are caused when the fault condition remains for a long time. Fuel cell performs optimum in the standard conditions of operating temperature, and humidity [14]. Reactant gases are humidified before entering the fuel cell. The gases in tern humidify the membrane. The proton exchange membrane has a special characteristic of conducting hydrogen protons. The proton conductivity increases when the membrane is wet. On the converse, proton conductivity drops when the membrane is dried. The membrane dries up when either humidification is less, or the cell is operating at a higher temperature. Higher operating temperature evaporates the water inside the cell. Prolong such conditions damages the membrane. Pinholes form on the membrane. Hydrogen molecules directly travel to the cathode side, and the anode side reaction does not take place. On the other hand, if the temperature is under control but humidification is increased, or water removal from the fuel cell is not effective then, the water flooding situation arises. Water flooding inside the fuel cell reduces reaction rate hence, degrades fuel cell performance. Many researchers have worked to detect faults in the fuel cell system. The literature presented two approaches to fault detection. One is model-driven, and another is data-driven models [15,16]. In case of the data-driven approach deals with experimental data to detect faults. Whereas, the fuel cell model is developed, and the fault condition is detected by comparing model output versus actual output in the model-driven approach. Model output is usually compared with the fuel cell polarization curve ( $V-I)$ [17]. If the model predicted output in terms of the $V-I$ curve is within an acceptable error to the actual fuel cell $V$-I curve, then the model can be considered as a reliable model [18]. A battery is an electrochemical energy storage device. Its electrical equivalent model is studied by comparing the $V-I$ curve to ensure the correctness of the model [19]. Electrochemical impedance spectroscopy (EIS) is a commonly used technique to detect water flooding, and degradation [20,21]. EIS is also used for the state of health in electric vehicles [22]. The computer tomography technique is used for offline fault detection [23]. Fault conditions are detected, and isolated using artificial neural networks [24], and fuzzy logic [25]. Principle component analysis [26] is also used to study faults in the literature. The degradation in fuel cells needs to be detected, whether it is due to fault conditions or aging. Recently, few researchers are using a coefficient of variance $(\mathrm{CV})$ technique to compare data. Statistical tools skewness, and CV was used to measure voltage dispersion, and degree of asymmetry in fuel cell voltage [27]. CV was used to analyze the reliability of the fuel cell system using the stress-strength interference method [28]. CV is used in SOFC to study oxide ion flux, and open-circuit voltage [29]. Voltage attenuation study of fuel cell durability has used CV as a statistical tool to characterize voltage consistency [30]. CV was used recently in PEM fuel cell degradation, and consistency study as a test tool [31]. CV is proving as an effective tool to compare parameters from two datasets. It is simple to calculate. Hence, it can be easily implemented in an embedded system that is necessary for on-board monitoring of the fuel cell system. 
This paper presents experimental observations when the PEM fuel cell operates in various operating conditions. It includes observations of performance degradation between new, and used fuel cells of the same size. Fuel cell performance degradation due to the fault conditions is studied by simulating the fault conditions experimentally. When the fuel cell degrades, its output voltage drops for a given current density. Ultimately, it results in a drop in fuel cell output power density. The fuel cell performance degradation is studied on an aged cell, and after injecting fault in the fuel cell system. The degradation is analyzed by comparing fuel cell output voltage, and power for a current density of the new cell, and the aged cell or after injecting fault in the fuel cell system. Moreover, the degradations due to faults, and aging are quantified based on the experimental results. Further, the paper proposes a CV based technique to detect the degradation in the PEM fuel cell performance. The rest of the paper is organized as follows: section 2 describes the PEM fuel cell, section 3 describes the experimental setup, section 4 presents experimental observations, section 5 analyses fuel cell degradation using CV, and section 6 concludes the paper.

\section{PEM FUEL CELL BASICS}

PEM fuel cell uses Hydrogen, and Oxygen as reactant gases. Hydrogen is supplied at the anode, and Oxygen at the cathode of the cell. Both the reactant gases flow through graphite made flow-fields. The reactant gases are spread on the membrane surface through a gas diffusion layer (GDL). GDL is made up of carbon. Platinum particles are deposited on the proton exchange membrane. Platinum is used as a catalyst in the fuel cell. PEM fuel cell construction, and working are shown in Fig. 3. At the anode, Hydrogen splits into electrons, and protons in a reduction reaction (1). The electrons flow through the external circuit, and protons travel through the membrane. Electrons, and the protons combine to become Hydrogen elements again at the cathode side. Refer reaction (2) for the Hydrogen formation at the cathode. The Hydrogen reacts with oxygen at the cathode to form water. Heat is generated out of the reaction as it is an exothermic reaction. Refer reaction (3) as a complete fuel cell reaction.

$$
\begin{gathered}
2 \mathrm{H}_{2}=4 \mathrm{H}^{+}+4 e^{-} \\
4 H^{+}+4 e^{-}=2 \mathrm{H}_{2} \\
\mathrm{O}_{2}+2 \mathrm{H}_{2}=2 \mathrm{H}_{2} \mathrm{O}+\text { energy }
\end{gathered}
$$

Though the PEM fuel cell is an electrochemical device, it involves multi-physical domains such as electrochemistry, thermodynamics, fluid mechanics, and material science. The PEM fuel cell potential is theoretically expressed by the Nernst Eq. (4).

$$
E=1.229-0.85 \times 10^{-3}\left(T_{f c}-298.15\right)+4.3085 \times 10^{-5} T_{f c}\left[\ln \left(P_{H_{2}}\right)+\frac{1}{2} \ln \left(P_{O_{2}}\right)\right]
$$

The PEM fuel cell temperature is $T_{f c}$ in K. Partial pressures of Hydrogen, and Oxygen are $P_{H_{2}}$, and $P_{O_{2}}$ respectively.

Practical fuel potential is lesser than E due to losses in the fuel cell. There are three types of losses in the PEM fuel cell; activation loss, ohmic loss, and concentration loss. Eq. (5) shows the PEM fuel cell potential after deducting the losses.

$$
V_{f c}=E-V_{a c t}-V_{o h m}-V_{c o n c}
$$

where, $V_{\text {act }}$ is an activation loss, $V_{\text {ohm }}$ is ohmic loss, and $V_{\text {conc }}$ is concentration loss. Activation loss is due to the potential loss that occurs when a current is being demanded by the load. The PEM fuel cell potential drops sharply as soon as a small current is sourced. The sharp potential drop occurs due to the break-and-form chemical bonds, and electrons transfer. It is the energy loss in driving the chemical reaction, and electron transfer. The activation loss is expressed in Eq. (6). 


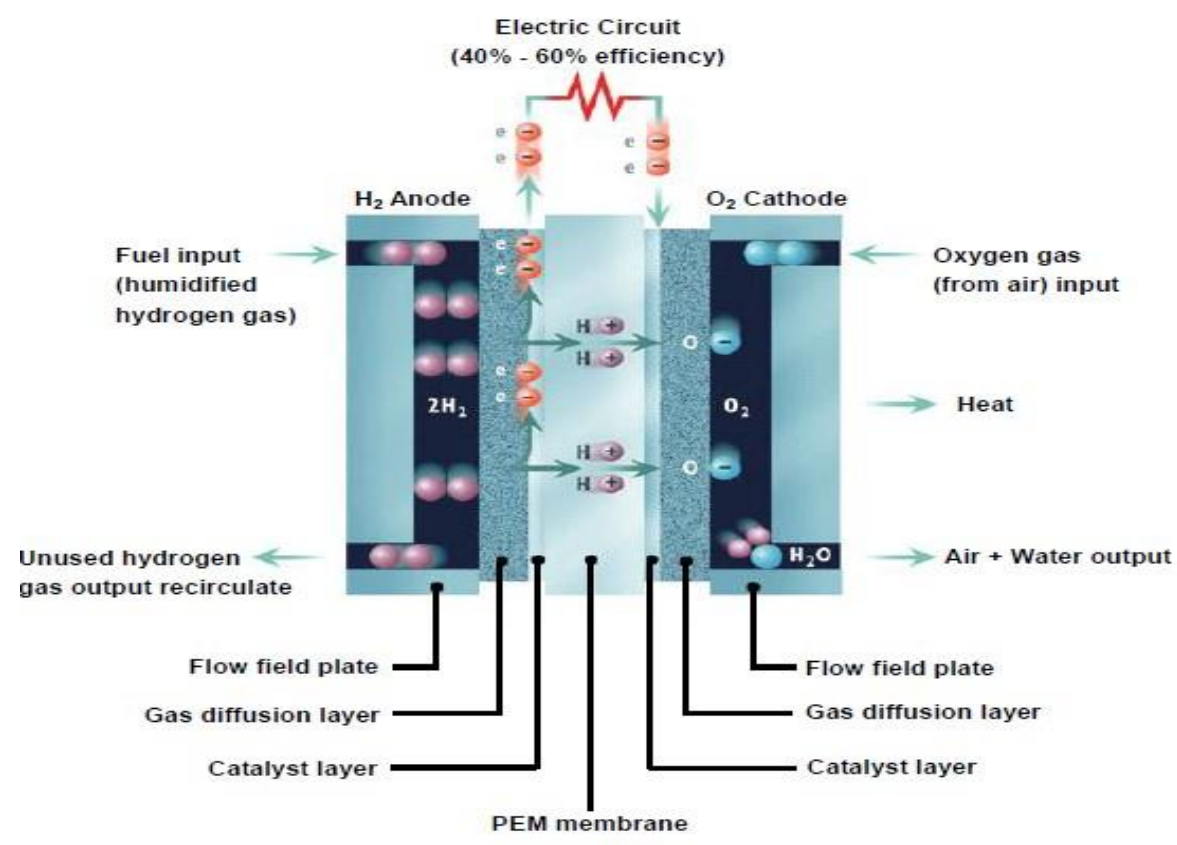

Figure 3. PEM fuel cell construction and operational sketch.

$$
V_{a c t}=V_{0}+V_{a}\left(1-e^{-c_{1} i}\right)
$$

Where, $V_{0}$ is potential at zero current density. $V_{a}$, and $C_{1}$ are constants. $V_{0}$ is a function of PEM fuel cell temperature, and reactant gases saturation pressure, $P_{\text {sat }}$. Whereas, $V_{a}$ is a function of PEM fuel cell temperature, reactant gases saturation pressure, and partial pressure of Oxygen, $P_{O_{2}}$. Eqs. $(7,8)$ calculate $V_{0}$, and $V_{a}$ respectively. The equations for the constants are,

$$
\begin{aligned}
& V_{0}=0.279-8.5 \times 10^{-4}\left(T_{f c}-298.15\right)+4.3085 \times 10^{-5} T_{f c}\left[\ln \left(\frac{P_{c a}-P_{s a t}}{1.01325}\right)+\frac{1}{2} \ln \left(\frac{0.1173\left(P_{c a}-P_{s a t}\right)}{1.01325}\right)\right] \\
& V_{a}=\left(-1.618 \times 10^{-5} T_{f c}+1.618 \times 10^{-2}\right)\left(\frac{P_{O_{2}}}{0.1173}+P_{s a t}\right)^{2}+\left(-1.8 \times 10^{-4} T_{f c}+0.166\right)\left(\frac{P_{O_{2}}}{0.1173}+P_{s a t}\right) \\
& +\left(-5.8 \times 10^{-4} T_{f c}+0.5736\right)
\end{aligned}
$$

The PEM fuel cell has an internal resistance, $R_{\text {ohm }}$ due to the polymer membrane, electrodes, and collector plates. This internal resistance causes ohmic loss in the PEM fuel cell. The ohmic loss is expressed as follows:

$$
V_{\text {ohm }}=i R_{\text {ohm }}
$$

The PEM fuel cell voltage drops rapidly when a high current is drawn by the load. It occurs due to a change in the concertation of reactant gases. Such a rapid drop at a high current is called concentration loss. The concentration loss can be calculated by an Eq. (10).

$$
V_{\text {conc }}=i\left[C_{2} \frac{i}{i_{\max }}\right]^{c_{3}}
$$

Where, $C_{2}, C_{3}$, and $i_{\max }$ are constants.

The current density of the fuel cell is current per cell area. The current density formula is shown in Eq. (11).

$$
\text { Current Density }=\frac{i}{A}
$$


Where, $i$ is fuel cell current, and $A$ is cell active area.

The PEM fuel cell polarization curve is shown in Fig. 4. The Fig. 4 shows a typical PEM fuel cell polarization curve, and losses. The potential drops due to the three losses; Activation losses, ohmic losses, and mass transport losses.

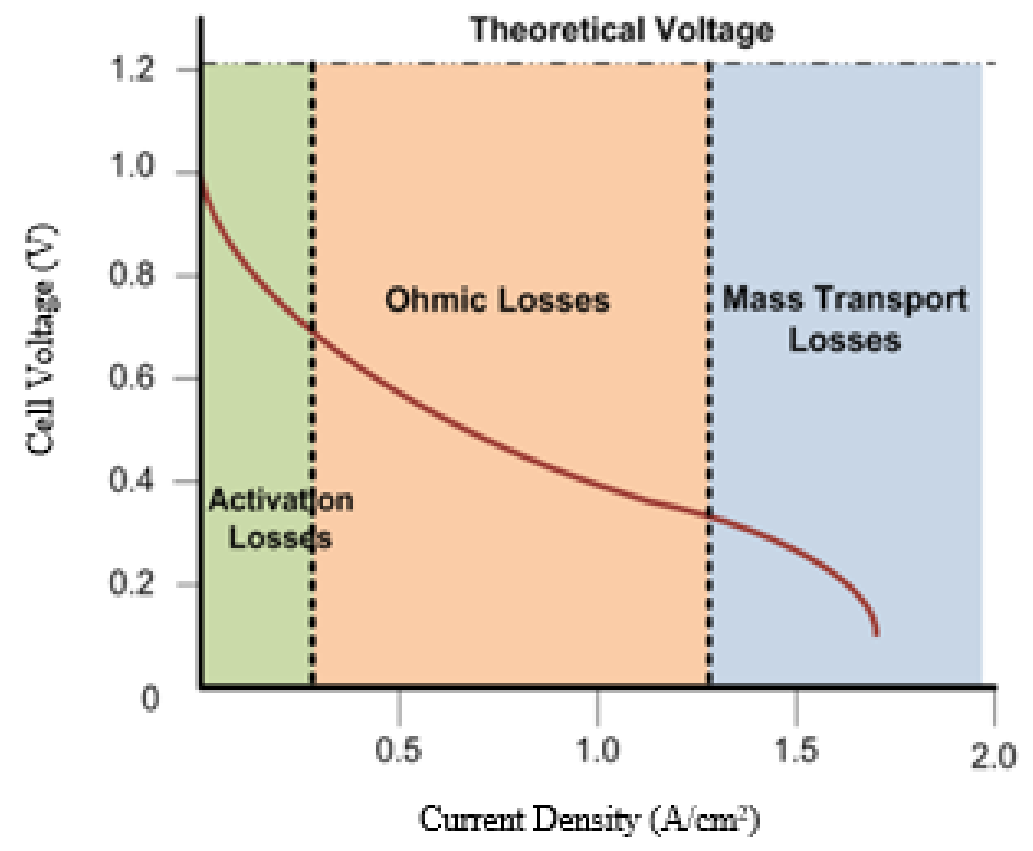

Figure 4. PEM fuel cell polarization curve, and losses.

\section{EXPERIMENTAL SETUP}

A single cell of $25 \mathrm{~cm}^{2}$ area was used in the experimentation. The cells were made by PaxiTech. The experiments were conducted on unused/new MEA as well as aged MEA. Fig. 5 shows unused, and used/aged MEAs. Mechanical damage or abrasion can be seen on the used MEA. A fuel cell using unused MEA produces a polarization curve with appropriate current density. Hence, the experimental data can be benchmarked to compare with the polarization curve obtained through other experiments. Nafion-115 proton exchange membrane is used in the MEA. Graphite serpentine flow channels were used in the flow field plate. The MEA membrane is sandwiched between two flow field plates. Gold plated current plates are placed on both sides as anode, and cathode electrodes. The entire assembly is then secured in stainless steel plates. The PEM fuel cell components, and the assembled cell is shown in Fig. 6. The specifications of the PEM fuel cell used in experimentation are listed in Table 1.

The experiments were conducted using a PEM fuel cell hardware-in-loop tester, FCT-50S. FCT-50S is developed by PaxiTech, and Bio-Logic Science Instruments. The cells can be connected to the tester as shown in Fig. 7. The cell is supplied with the reactant gases Oxygen and Hydrogen. The reactant gases are humidified by the humidifier which is in-built in the tester. Fig. 8 shows the internal instrumentation of the tester. The reactant gases are supplied to the tester through compressed cylinders. Medical grade Oxygen, and 99\% pure Hydrogen were used in the experiments. Nitrogen gas is also one of the inputs to the tester. Nitrogen is used to purge the cell before, and after the experiment. It flushes out water from the field flow if trapped during the experimentation. The tester maintains the temperature of the cell through a heater. The tester has pressure gauges, and indicators for cell voltage, current, and temperature. The tester is connected to the computer through ethernet. A computer software, FC-Lab is used to interface with the tester. 


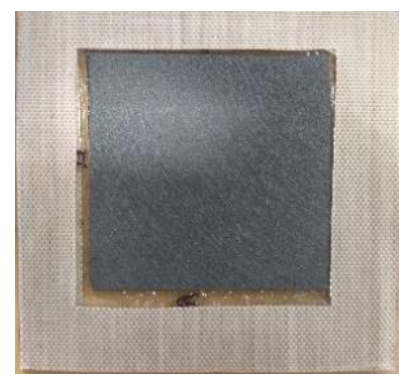

(a)

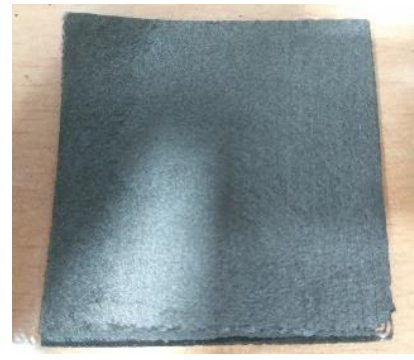

(b)

Figure 5. MEAs used in the experiments: (a) Unused MEA, (b) Used MEA.
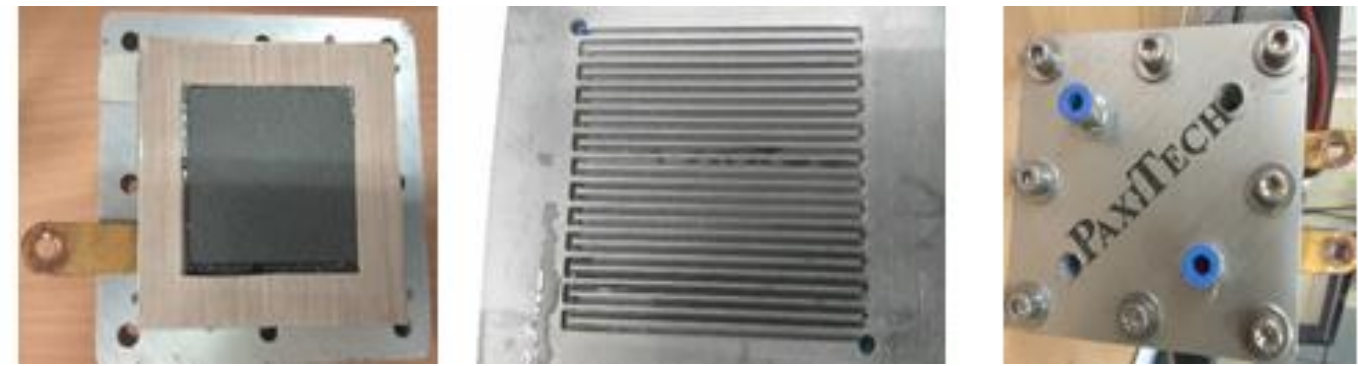

Figure 6. PEM Fuel cell assembly in different views.

Table 1. PEM fuel cell materials.

\begin{tabular}{ll}
\hline \multicolumn{1}{c}{ Component } & \multicolumn{1}{c}{ Material } \\
\hline Membrane & Nafion-115 \\
Catalyst Layer & Pt/C \\
GDL & Carbon paper \\
Flow Field & Graphite - NCK 194 grade \\
Current Collector & Gold plated copper \\
End plates & Stainless Steel \\
Gaskets & Rubber \\
\hline
\end{tabular}

Tests can be configured, scheduled, executed, and result analysis can be performed using the software. Moreover, it logs experimental data which can be used for further offline analysis. Fig. 9 shows the main window of the FC-Lab. The tester can perform tests like electrochemical impedance spectroscopy (EIS), cyclic voltammetry, voltage pulse, current pulse, current interruption, load pulse, and fuel cell internal voltage. The tester analyzes test results by drawing Bode, and Nyquist plots. Table 2 lists the specifications of the tester, FCT-50S.

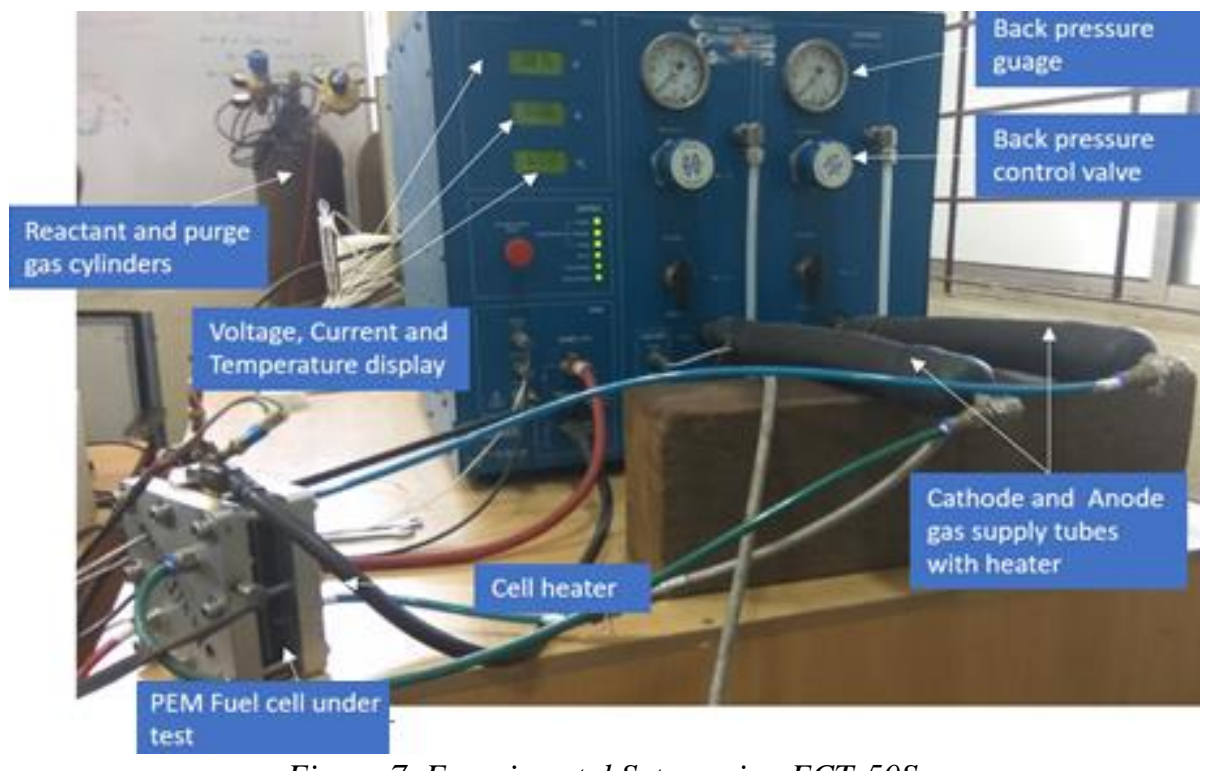

Figure 7. Experimental Setup using FCT-50S. 


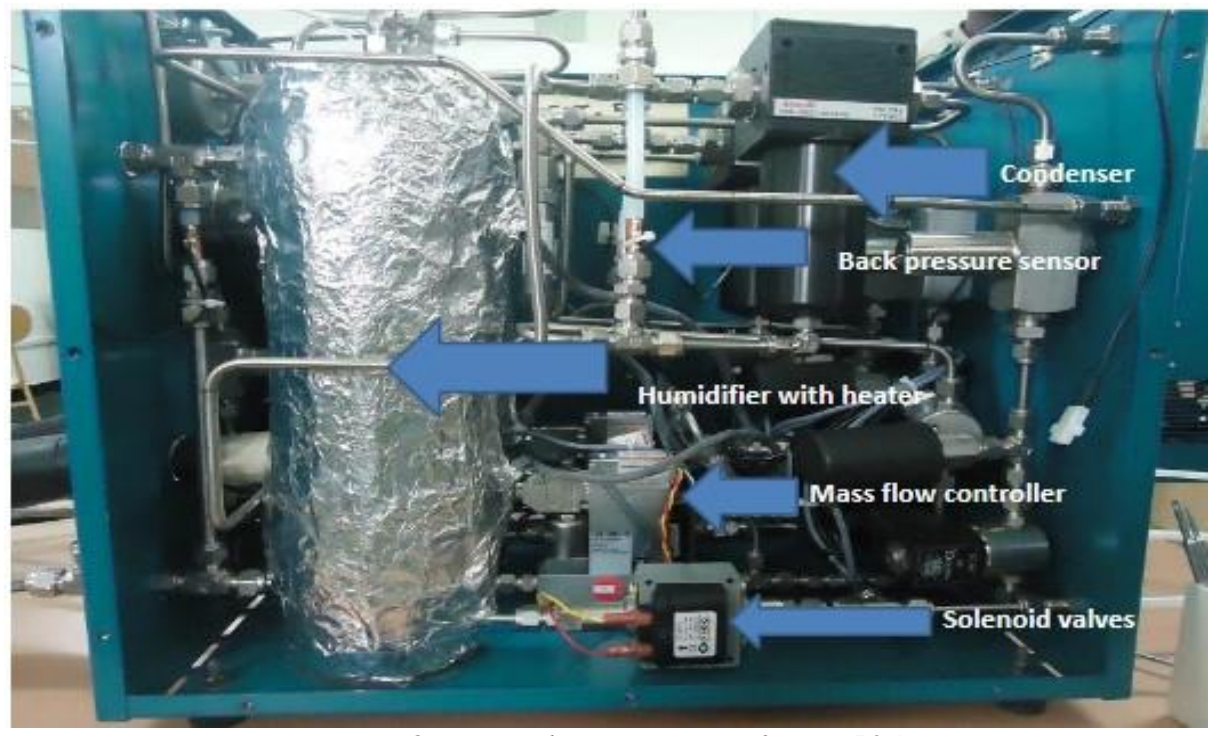

Figure 8. Internal components of FCT-50S.

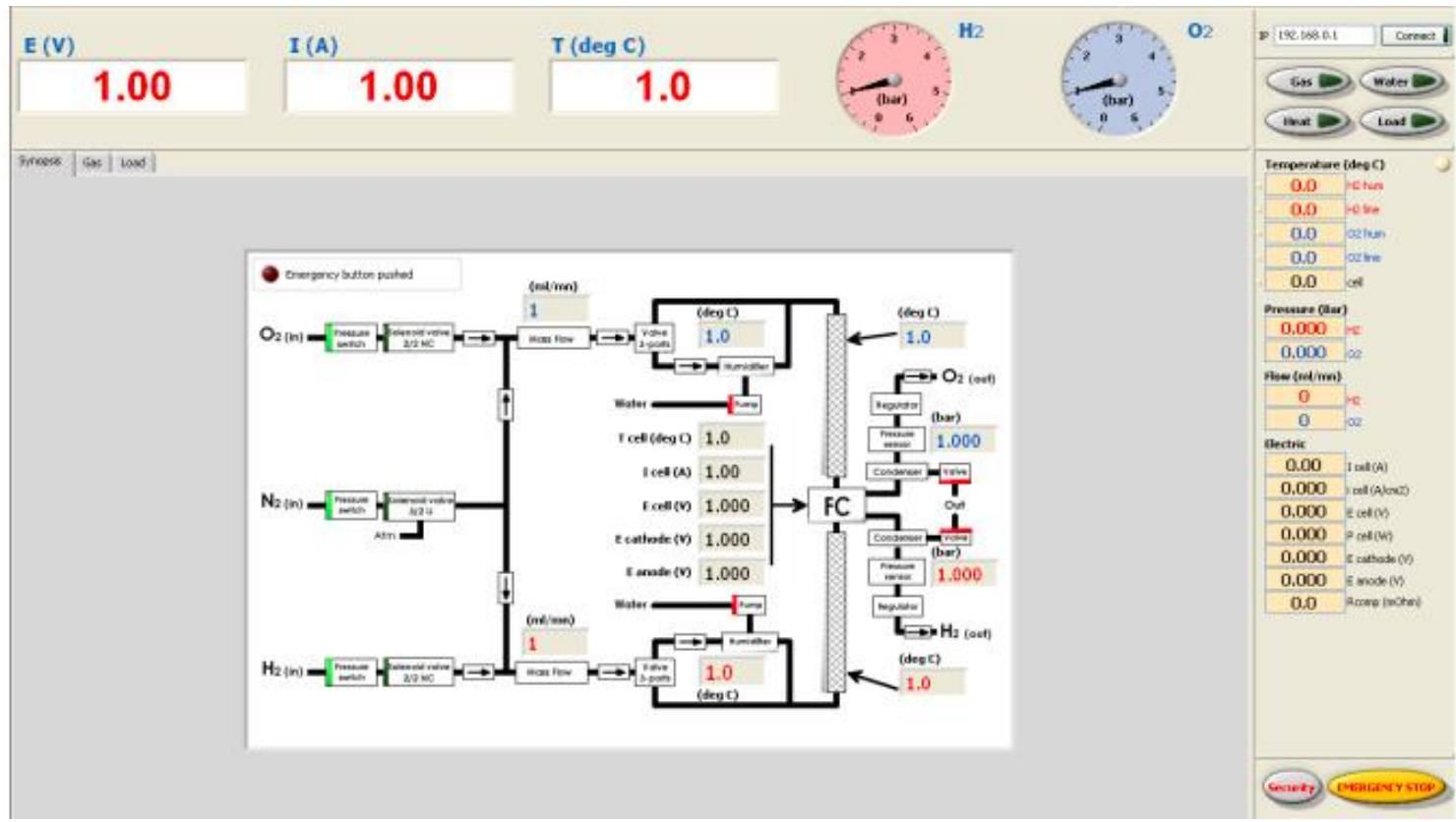

Figure 9. FC-Lab main window.

Table 2. Specifications of FCT-50S.

\begin{tabular}{ll}
\hline \multicolumn{1}{c}{ Parameters } & \multicolumn{1}{c}{ Specifications } \\
\hline Maximum load current & $50 \mathrm{~A}$ \\
Current measurement accuracy & $0.5 \%$ of Full Scan Range (FSR) \\
Minimum load current & $30 \mathrm{~mA}$ \\
Current resolution & $4 \mathrm{~mA}$ \\
Maximum voltage & $5 \mathrm{~V}$ \\
Potential measurement accuracy & $<0.1 \% \mathrm{FSR}$ \\
Potential resolution & $76 \mu \mathrm{V}$ \\
Frequency range & $10 \mu \mathrm{Hz}$ to $10 \mathrm{kHz}$ \\
Data acquisition & 10000 samples $/ \mathrm{s}$ \\
Temperature controller & 5 heater PID controllers \\
Probe & Pt100 \\
Humidifiers & $100 \%$ saturation at 87 degree Centigrade \\
Mass flow control & Hydrogen: $0-40 \mathrm{~L} / \mathrm{h}$ Oxygen: $0-100 \mathrm{~L} / \mathrm{h}$ \\
Back pressure control & $0-5$ Bars \\
\hline
\end{tabular}




\section{EXPERIMENTAL OBSERVATIONS}

The purpose of the experimentation is to monitor, and validate the PEM fuel cell performance degradation due to aging, and degradation at fault conditions. Various experiments were conducted to observe the performance degradation. We used two fuel cells in the experimentation. One had a new membrane assembly, and another was an aged membrane. The aged membrane had run more than 2000 hours. Fault conditions are simulated on the cell using an aged membrane. Voltage scan tests were executed on the fuel cells as per test parameters in Table 3.

Table 3. Voltage scan test conditions and test parameters.

\begin{tabular}{llll}
\hline Cell Temperature & $50{ }^{\circ} \mathrm{C}$ & Voltage & $0.9 \mathrm{~V}$ \\
Purge Flow & $100 \mathrm{~mL} / \mathrm{min}$ & Scan Rate & $0(\mathrm{~V} / \mathrm{s})$ \\
$\mathrm{H}_{2}$ ratio & 100 & Vs initial & $0(\mathrm{~V} / \mathrm{s})$ \\
$\mathrm{O}_{2}$ ratio & 100 & Voltage & $0.4 \mathrm{~V}$ \\
Flow $\mathrm{H}_{2}$ & $550 \mathrm{~mL} / \mathrm{min}$ & Scan Rate & 5.0 \\
Coefficient stoechio $\mathrm{H}_{2}$ & 1.1 & Scan & 0 \\
Humidifier Temperature $\mathrm{H}_{2}$ & $50{ }^{\circ} \mathrm{C}$ & N Cycles & 1 \\
Line Temperature $\mathrm{H}_{2}$ & $50{ }^{\circ} \mathrm{C}$ & Record & $>0.003$ \\
Flow $\mathrm{O}_{2}$ & $280 \mathrm{~mL} / \mathrm{min}$ & Begin & $0.5 \mathrm{~A}$ \\
Coefficient stoechio $\mathrm{O}_{2}$ & 2 & End & $0.75 \mathrm{~A}$ \\
Humidifier Temperature $\mathrm{O}_{2}$ & $50{ }^{\circ} \mathrm{C}$ & I Range & $11 \mathrm{~A}$ \\
Line Temperature $\mathrm{O}_{2}$ & $50{ }^{\circ} \mathrm{C}$ & E Range & $1 \mathrm{~V}$ \\
\hline
\end{tabular}

\subsection{Voltage scan test on PEM fuel cell having new membrane assembly}

A fuel cell was assembled with the unused membrane. It simulated zero-hour operation that means the performance shall be optimum at standard operating parameters. The assembled fuel cell was connected to the FCT-50S. The cell was purged by compressed Nitrogen to ensure clean flow-fields. The voltage scan test was executed. Voltage, and current values were logged for further analysis. Similarly, another fuel cell was assembled with the aged membrane. The degraded cell performance was expected at the standard operating conditions. The cell was connected to the FCT-50S, the cell purged with Nitrogen to ensure clean field-flow, and executed the voltage scan test. Voltage and current values were logged to further analysis. The aged membrane can be seen with minor mechanical damages.

Fig. 10 shows the comparison between the cell performances. Solid black lines are the polarization, and power density curves for the new membrane assembly fuel cell. Whereas, dotted black lines are the polarization, and power density curves for the aged membrane assembly fuel cell. Polarization curves have a primary $y$-axis, and power density curves have a secondary $y$-axis. The current density is on the $x$-axis. Current, and power densities of the aged cell were degraded by almost $90 \%$ to the new cell. EIS test was performed on both cells, and their result is shown in Figs. 11,12. The degradation of the aged cell can be seen from the Bode plot. 

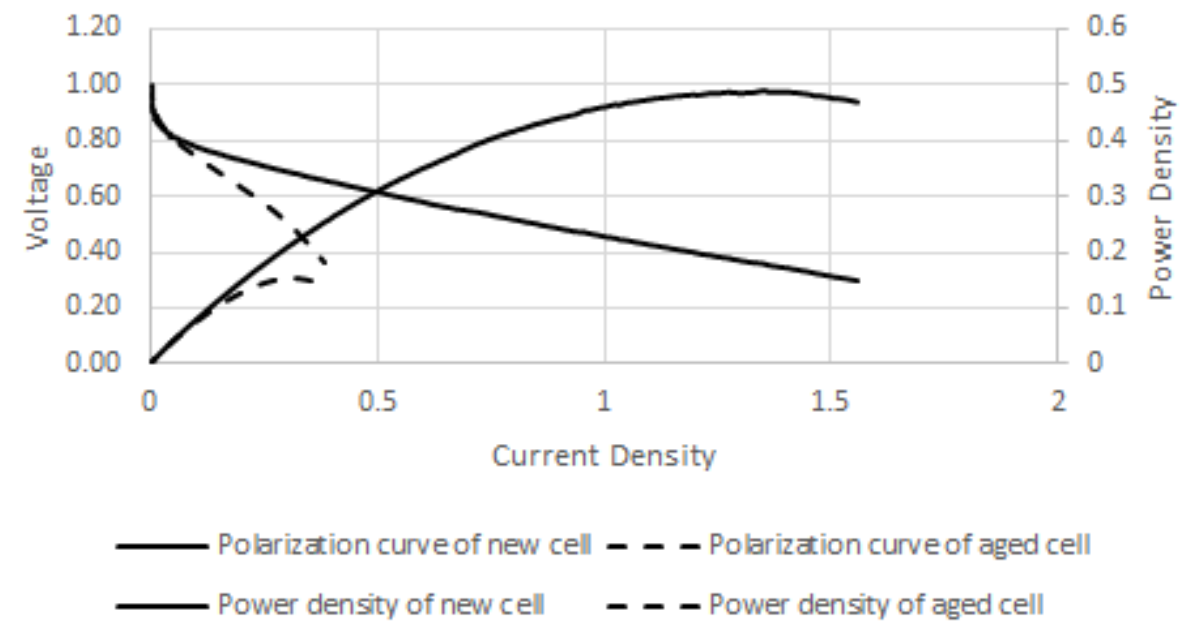

Figure 10. PEM fuel cell performance comparison when used new and aged membrane assemblies.

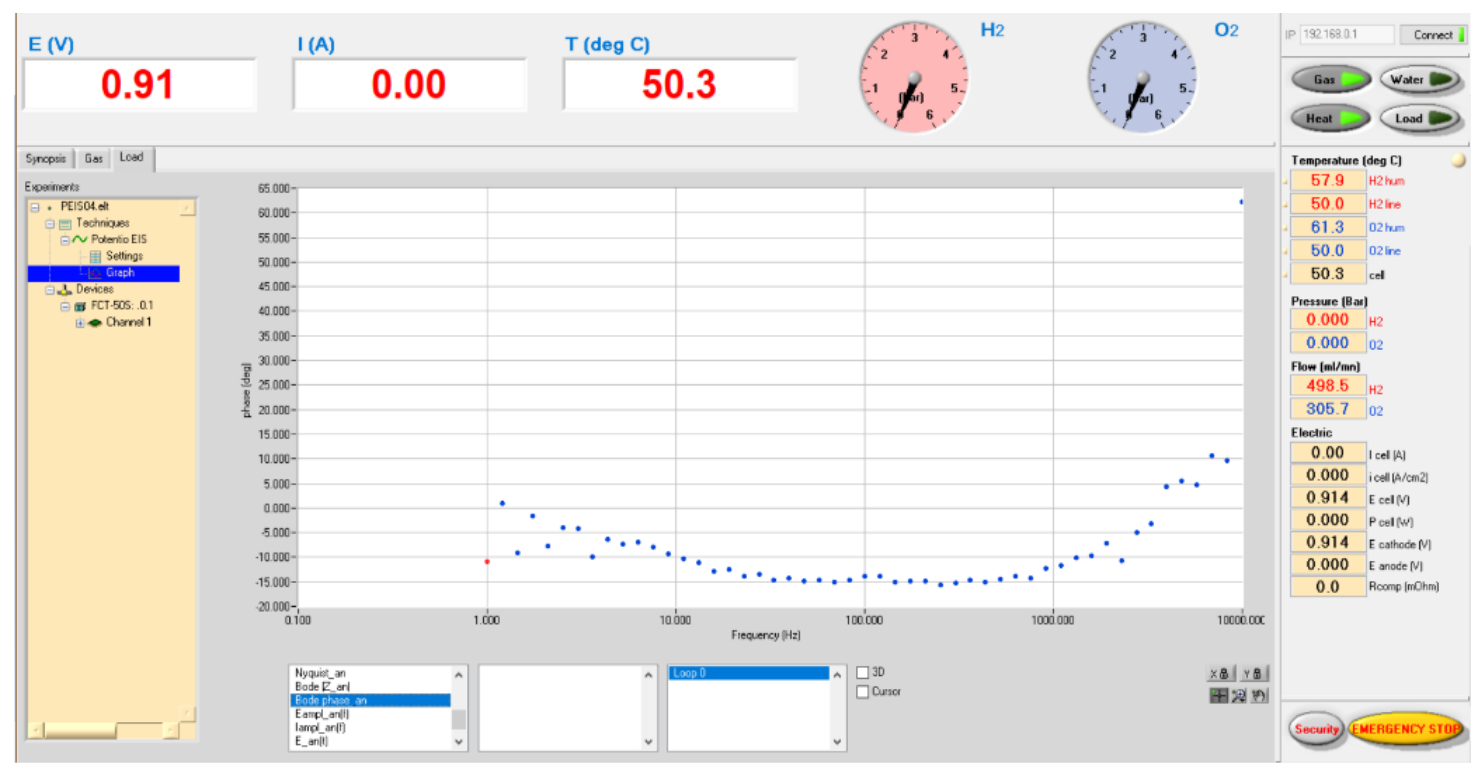

Figure 11. Bode plot of EIS test on new MEA fuel cell.

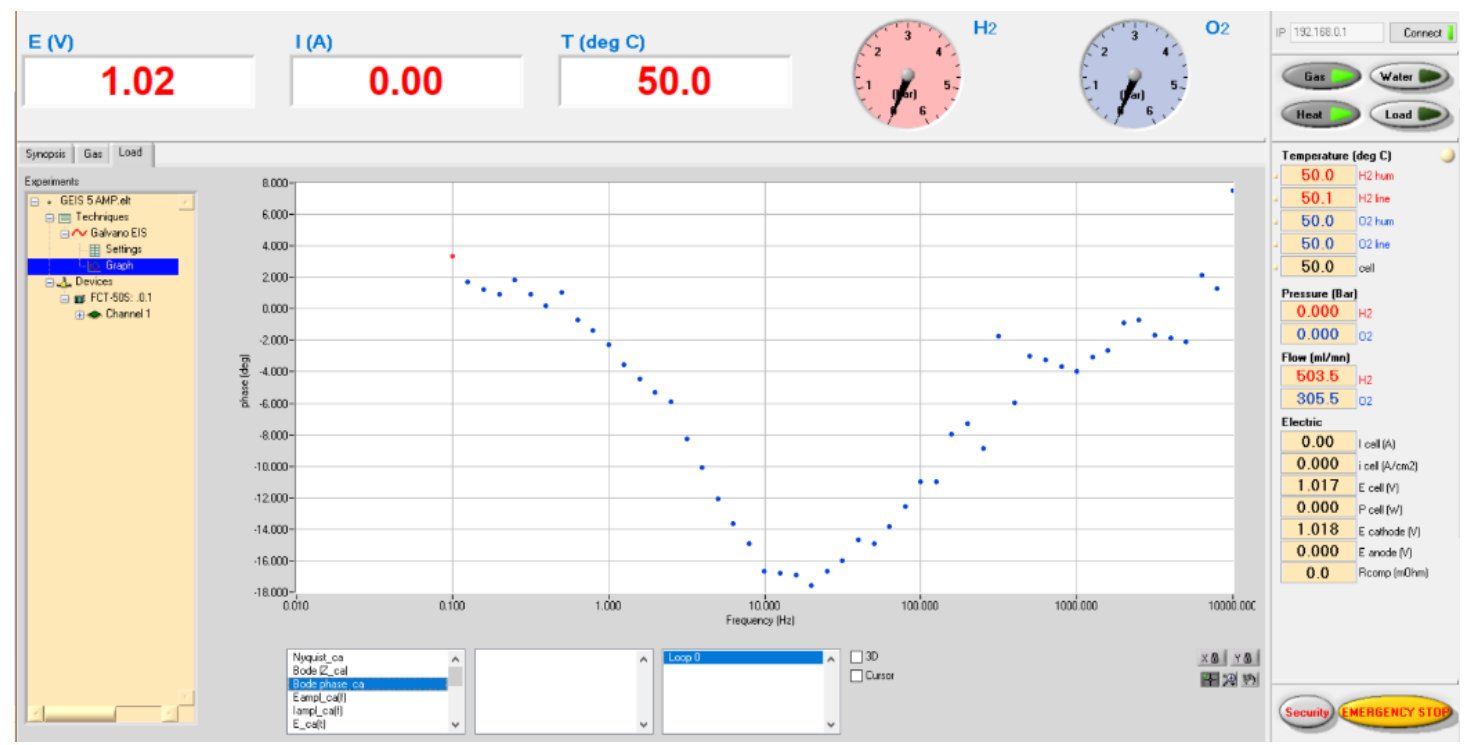

Figure 12. Bode plot of EIS test on aged MEA fuel cell. 


\subsection{Voltage scan test on PEM fuel cell when operated in water flooding condition}

Water flooding is one of the common faults in the PEM fuel cells. The fault condition arises when the fuel cell goes under frequent current cycles, humidification of reactant gases is high, and water is blocked in the side of the flow-fields. Water flooding reduces the reaction rate hence drops power output.

Experimentally, the flooding situation was created by frequent current cycling tests, and by blocking the water outlet of the fuel cell. Then, a voltage scan test was executed. Voltage, and current values were logged for further analysis. Fig. 13 shows the difference in fuel cell performance when operated under a water flooding situation with respect to the fuel cell working in standard operating conditions. PEM fuel cell performance dropped by around $30 \%$ when operated in the water flooding condition.

\subsection{Voltage scan test on PEM fuel cell when operated in reactant gas starvation condition}

Reactant gas starvation fault conditions can arise when there is an issue in the gas delivery system. When the fuel cell does not receive the required quantity of reactant gas then, the cell starves. The starving cell degrades performance because the reaction rate is slow. The prolonged starvation condition can damage the membrane.

The condition was simulated by partially opening the Hydrogen gas valve. The cell was purged with Nitrogen to ensure there is no other fault condition present. Then, a voltage scan test was executed. Voltage, and current values were logged for further analysis. Fig. 14 shows the difference in fuel cell performance when operated under a starving condition with respect to the fuel cell working in standard operating conditions. PEM fuel cell performance dropped by around 55\% when operated in the reactant gas starvation condition.

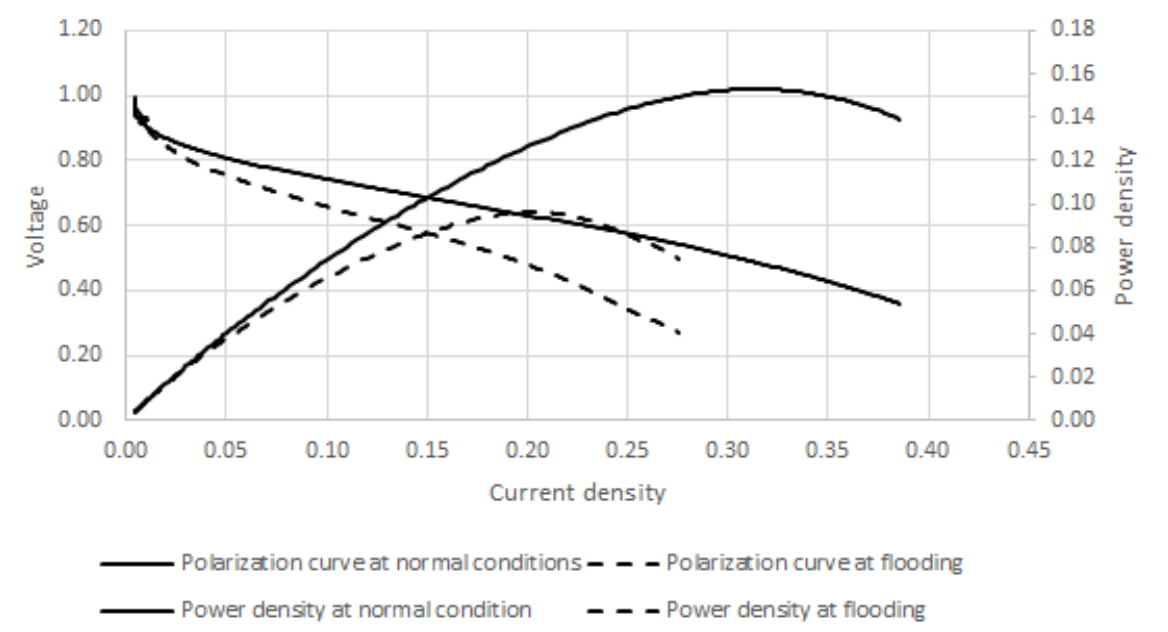

Figure 13. PEM fuel cell performance comparison when operated in standard condition versus water flooding condition. 


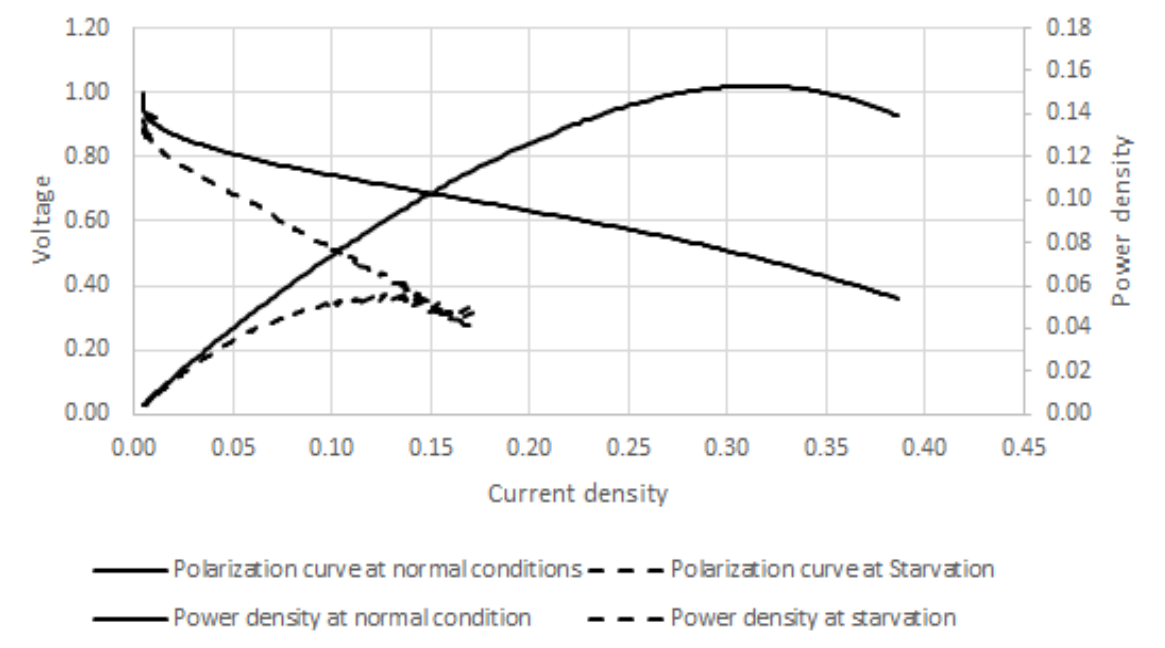

Figure 14. PEM fuel cell performance comparison when operated in standard condition versus starvation condition.

\subsection{Voltage scan test on PEM fuel cell when operated in a high-temperature condition}

The PEM fuel cell under test has a standard operating temperature $50^{\circ} \mathrm{C}$. However, for experimentation purposes, it was operated at $100^{\circ} \mathrm{C}$. Usually, fuel cell temperature increases if the thermal control is poor for the fuel cell system.

The cell was purged with Nitrogen to ensure there is no other fault condition present. Then, a voltage scan test was executed. Voltage, and current values were logged for further analysis. Fig. 15 shows the difference in fuel cell performance when operated under the high-temperature conditions with respect to the fuel cell working in standard operating conditions. PEM fuel cell almost did not work when operated at $100^{\circ} \mathrm{C}$. High-temperature cases multiple effects on the fuel cell. It evaporates the water inside the fuel cell. It leads to a dry membrane. Hence, proton conductivity is restricted. It results in almost no reaction on the cathode side.
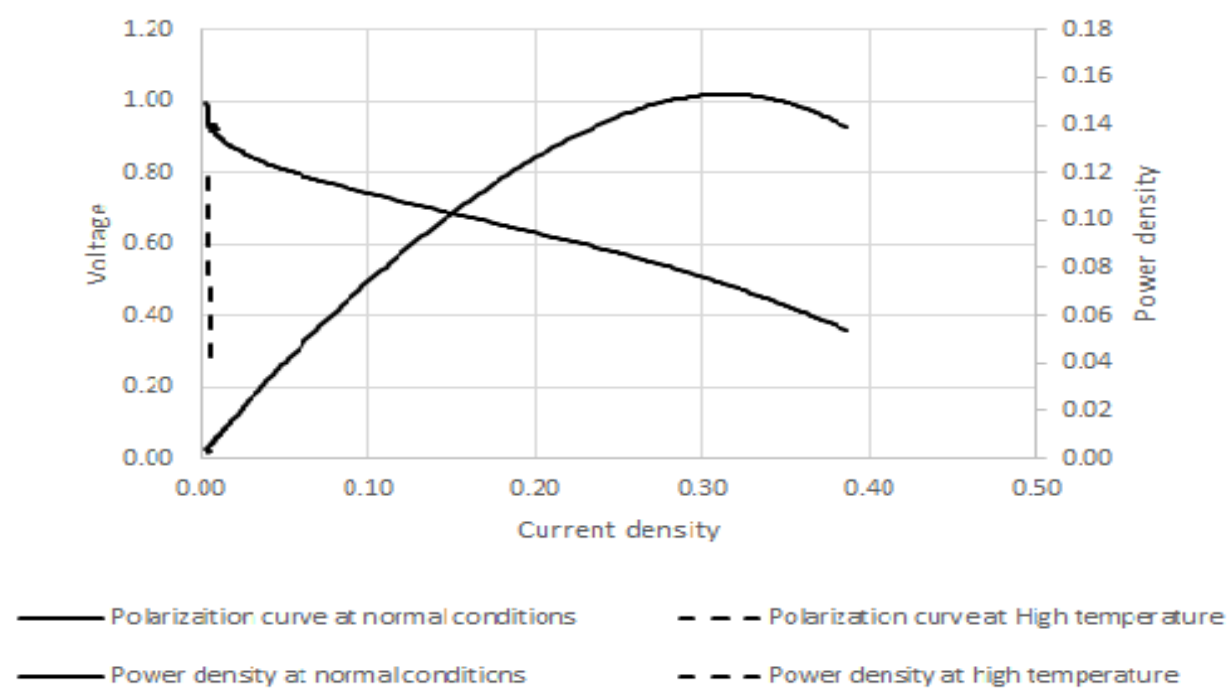

Figure 15. PEM fuel cell performance comparison when operated in standard condition versus high-temperature condition. 


\section{PEM FUEL CELL DEGRADATION DETECTION}

Experimental observations have shown that the PEM fuel cell performance degrades due to aging, and faults. This is also proven in the literature so far. Fault conditions degrade fuel cell performance suddenly, and can be temporary in nature. The performance can recover if the fault condition is removed. However, if the fault condition is not detected, and the cell operates under such fault condition for a long time then, it develops permanent mechanical damage. Mechanical damage can be due to corrosion, developing cracks, or pinholes in the membrane, and erosion of the catalyst layer. Detection, and correction of the fault condition can improve the useful life of the fuel cell. Moreover, degradation due to aging confirms the cell capacity.

Fuel cell performance shall be captured, and benchmarked when the MEA is unused, and all operating conditions are optimum. The cell performance while in operation shall be compared with the captured performance. Deviation in performance can indicate either presence of fault condition or aging. We propose, CV method to compare the performance parameters of the fuel cell. The CV is a useful index to compare results from two data sets. Moreover, $\mathrm{CV}$ is a measure of relative variability. It is the ratio of the standard deviation, $\sigma$ to the mean, $\mu$. CV is often expressed in percentage. It is calculated as per Eq. (12). Eqs. $(13,14)$ are to calculate mean $\mu$, and standard deviation $\sigma$ respectively.

$$
C V=\frac{\sigma}{\mu} 100 \%
$$

where,

$$
\begin{gathered}
\mu=\frac{\sum_{k}^{N} X_{k}}{N} \\
\sigma=\sqrt{\frac{1}{N} \sum_{k}^{N}\left(X_{k}-\mu\right)^{2}}
\end{gathered}
$$

$N$ is the number of data points.

$\mathrm{CV}$ is calculated for the fuel cell voltage $\left(\mathrm{CV}_{\mathrm{V}}\right)$, current density $\left(\mathrm{CV}_{\mathrm{CD}}\right)$, and cell power $\left(\mathrm{CV}_{\mathrm{P}}\right) . \mathrm{CV}_{\mathrm{V}}$, $\mathrm{CV}_{\mathrm{CD}}$, and $\mathrm{CV}_{\mathrm{P}}$ are calculated for every experiment condition. The values obtained for all experiments are listed in table 4.

Table 4. CV analysis results.

\begin{tabular}{lccccc}
\hline $\mathrm{CV}$ & $\begin{array}{c}\text { Unused membrane with } \\
\text { appropriate operating } \\
\text { conditions }\end{array}$ & $\begin{array}{c}\text { Used/aged membrane } \\
\text { with appropriate } \\
\text { operating conditions }\end{array}$ & $\begin{array}{c}\text { Cell flooding } \\
\text { fault condition }\end{array}$ & $\begin{array}{c}\text { Reactant gas } \\
\text { starvation fault } \\
\text { condition }\end{array}$ & $\begin{array}{c}\text { High operating } \\
\text { temperature fault } \\
\text { condition }\end{array}$ \\
\hline $\mathrm{CV}_{\mathrm{V}}$ & $29.79 \%$ & $27.05 \%$ & $31.37 \%$ & $31.33 \%$ & $28.09 \%$ \\
$\mathrm{CV}$ & $83.22 \%$ & $77.14 \%$ & $62.03 \%$ & $64.20 \%$ & $10.73 \%$ \\
$\mathrm{CV}$ & $65.29 \%$ & $63.06 \%$ & $44.00 \%$ & $44.75 \%$ & $18.95 \%$ \\
\hline
\end{tabular}

\section{CONCLUSION}

The paper has presented various operating situations in the lifetime of the PEM fuel cell. The PEM fuel cell degrades over time. The cell undergoes mechanical degradation when operated for a long time due to aging. The fuel cell degradation results in a drop in fuel cell output voltage, and power density for a current density. The drop in output voltage, and power density is analyzed by comparing data of new fuel cell operating in desired conditions. Experimentally, it was demonstrated that the performance was degraded around $90 \%$ in the aged fuel cells. Fuel cell performance also degrades due to fault conditions. Instantaneous fault conditions were experimentally created to study the degradation. The most common faults were chosen in the study. Poor water, and thermal management lead to water flooding, and high- 
temperature faults. Reactant gas starvation fault is caused if the gas delivery system has an issue. PEM fuel cell performance degradation was observed more than $30 \%$ during the fault conditions. The current density of fuel cell drops substantially in aging, and fault conditions when compared with fuel cell operated in desired operating conditions. Also, the power output of the fuel cell drops. Prolonged fault conditions may damage the cell further, and reduce its remaining useful life. Furthermore, the paper proposes an approach to detect degradation of the PEM fuel cell while in operation. CV has proven as a useful tool to compare fuel cell data with the benchmarked data. CV values for current density, and power are lesser in aging, and fault conditions as compared to appropriate operating conditions. Whereas, there is no substantial change in CV for fuel cell voltage in all the operating conditions. Hence, lesser CV values for current density, and power indicate the degradation in performance. This helps in detecting whether the fuel cell is operating under any fault condition. Faulty conditions can be corrected further to improve fuel cell useful life. The experiments have proved that fuel cell output is adversely affected due to aging or prolong use, and fault conditions that may present during the fuel cell operation. A statistical method CV has proven in the detection of the degradation in fuel cell output. Detection of fuel cell degradation can help in improving fuel cell operating conditions to avoid fault conditions.

\section{Acknowledgment}

This work was supported by the Department of Automobile Engineering, PSG College of Technology, Coimbatore, India for providing resources like PEM fuel cells, and experimentation setup. We sincerely thank Dr. P. Karthikeyan for his guidance. We are thankful to his research group for helping me in the experimentation.

\section{REFERENCES}

[1] Monthly Energy Review April 2020. U. S. Energy Information Administration, Office of Energy Statistics, U. S. Department of Energy, Washington, DC.

[2] Thompson, ST, Papageorgopoulos, D. Platinum group metal-free catalysts boost cost competitiveness of fuel cell vehicles. Nature Catalysis 2019; 2: 558-561.

[3] Gaikwad, SD, Ghosh, PC. Sizing of fuel cell electric vehicle: A pinch analysis-based approach. International Journal of Hydrogen Energy 2020; 45(15): 8985-8993, DOI: 10.1016/j.ijhydene.2020.01.116

[4] Khan, SS, Shareef, H, Mutlag, AH. Dynamic temperature model for proton exchange membrane fuel cell using online variations in load current and ambient temperature. International Journal of Green Energy 2019; 16(5): 361-370, DOI: 10.1080/15435075.2018.1564141

[5] Lue, X, Qu, Y, Wang, Y, Qin, C, Liu, G. A comprehensive review on hybrid power system for PEMFC-HEV: issues and strategies. Energy Convers Manag 2018; 171: 1273-91, DOI: 10.1016/j.enconman.2018.06.065

[6] Vichard, L, Harel, F, Ravey, A, Venet, P, Hissel, D. Degradation prediction of PEM fuel cell based on artificial intelligence. International Journal of Hydrogen Energy 2020; 45(29): 14953-14963, DOI: 10.1016/j.jijhydene.2020.03.209

[7] Wang, Z. Lifetime Prediction Modeling of Automotive Proton Exchange Membrane Fuel Cells. SAE Technical Paper 2019; 2019-01-0385, DOI: 10.4271/2019-01-0385

[8] Detti, AH, Steiner, NY, Bouillaut, L, Same, AB, Jemei, S. Fuel Cell Performance Prediction using an AutoRegressive Moving-Average ARMA Model. In: IEEE Vehicle Power and Propulsion Conference; 14-17 October 2019: IEEE, DOI: 10.1109/VPPC46532.2019.8952535

[9] Kim, TY, Kim, BS, Park, TC, Yeo, YK. Development of Predictive Model based Control Scheme for a Molten Carbonate Fuel Cell (MCFC) Process. International Journal of Control, Automation and Systems 2018; 16(2): 791-803, DOI: 10.1007/s12555-016-0234-0

[10] Zhou, D, Al-Durra, A, Zhang, K, Ravey, A, Gao, F. Online remaining useful life prediction of proton exchange membrane fuel cells using a novel robust methodology. Journal of Power Sources 2018; 399: 314328, DOI: 10.1016/j.jpowsour.2018.06.098

[11] Davies, B, Jackson, L, Dunnett, S. Expert diagnosis of polymer exchange fuel cells. International Journal of Hydrogen Energy 2017; 42: 11724-11734, DOI: 10.1016/j.ijhydene.2017.02.121

[12] Mao, L, Jackson, L, Jackson, T. Investigation of polymer electrolyte membrane fuel cell internal behaviour during long term operation and its use in prognostics. Journal of Power Sources 2017; 362: 39-49, DOI: 10.1016/j.jpowsour.2017.07.018 
[13] Chen, K, Laghrouche, S, Djerdir, A. Degradation model of proton exchange membrane fuel cell based on a noval hybrid method. Applied Energy 2019; 252: 113439, DOI: 10.1016/j.apenergy.2019.113439

[14] Barhate, SS, Mudhalwadkar, R, Prakash, AK. A survey on factors affecting performance and durability of PEM Fuel Cells in Automotive applications. International Journal of Control Theory and Applications 2017; 10(9): 659-669.

[15] Liu, H, Chen, J, Hou, M, Shao, Z, Su, H. Data-based short-term prognostics for proton exchange membrane fuel cells. International Journal of Hydrogen Energy 2017; 42: 20791-20808, DOI: 10.1016/j.ijhydene.2017.06.180

[16] Hissel, D, Pera, MC. Diagnostic \& health management of fuel cell systems: Issues and solutions. Annual Reviews in Control 2016; 42: 201-211, DOI: 10.1016/j.arcontrol.2016.09.005

[17] Saadi, A, Becherif, M, Aboubouc, A, Ayad, MY. Comparison of proton exchange membrane fuel cell static models. Renewable Energy 2013; 56: 64-71, DOI: 10.1016/j.renene.2012.10.012

[18] Pathapati, PR, Xue, X, Tang, J. A new dynamic model for predicting transient phenomena in a PEM fuel cell system. Renewable Energy 2005; 30: 1-22, DOI: 10.1016/j.renene.2004.05.001

[19] Chen, M, Rincon-Mora, GA. Accurate Electrical Battery Model Capable of Predicting Runtime and I-V Performance. IEEE Transactions on Energy Conversion 2006; 21(2): 504-511, DOI: 10.1109/TEC.2006.874229

[20] Ritzberger, D, Striednig, M, Simon, C, Hametner, C, Jakubek, S. Online estimation of the electrochemical impedance of polymer electrolyte membrane fuel cells using broad-band current excitation. Journal of Power Sources 2018; 405: 150-161, DOI: 10.1016/j.jpowsour.2018.08.082

[21] Jeppesen, C, Araya, SS, Sahlin, SL, Thomas, S, Andreasen, SJ, Kaer, SK. Fault detection and isolation of high temperature proton exchange membrane fuel cell stack under the influence of degradation. Journal of Power Sources 2017; 359: 37-47, DOI: 10.1016/j.ijhydene.2014.04.163

[22] Pivac, I, Bezmalinovic, D, Barbir, F. Catalyst degradation diagnostics of proton exchange membrane fuel cells using electrochemical impedance spectroscopy. International Journal of Hydrogen Energy 2018; 43: 13512-13520, DOI: 10.1016/j.ijhydene.2018.05.095

[23] Ifrek, L, Rosini, S, Cauffet, G, Chadebek, O, Rouveyre, L, Bultel, Y. Fault detection for polymer electrolyte membrane fuel cell stack by external magnetic field. Electrochimica Acta 2019; 313: 141-150, DOI: 10.1016/j.electacta.2019.04.193

[24] Abbaspour, A, Yen, KK, Forouzannezhad, P, Sargolzaei A. Active Adaptive Fault-Tolerant Control Design for PEM Fuel Cells. In: IEEE Energy Conversion Congress and Exposition, 23-27 September 2018: IEEE, DOI: 10.1109/ECCE.2018.8557620

[25] Pivac, I, Simic, B, Barbir, F. Experimental diagnostics and modeling of inductive phenomena at low frequencies in impedance spectra of proton exchange membrane fuel cells. Journal of Power Sources 2017; 365: 240-248, DOI: 10.1016/j.jpowsour.2017.08.087

[26] Lin, RH, Pei, ZX, Ye, ZZ, Guo, CC, Wu, BD. Hydrogen fuel cell diagnostics using random forest and enhanced feature selection. International Journal of Hydrogen Energy 2020; 45(17), 10523-10535, DOI: 10.1016/j.ijhydene.2019.10.127

[27] Noorkami, M, Robinson, JB, Meyer, Q, Obeisun, OA, Fraga, ES, Reisch, T, Shearing, PR, Brett, DJL. Effect of temperature uncertainty on polymer electrolyte fuel cell performance. International Journal of Hydrogen Energy 2014; 39: 1439-1448, DOI: 10.1016/j.ijhydene.2013.10.156

[28] Liu, LF, Liu, B, Wu, CW. Reliability prediction of large fuel cell stack based on structure stress analysis. Journal of Power Sources 2017; 363: 95-102, DOI: 10.1016/j.jpowsour.2017.06.041

[29] Nagasawa, T, Hanamura, K. Investigation of oxide ion flux at cathode/electrolyte interface in solid oxide fuel cell. Journal of Power Sources 2019; 412: 695-700, DOI: 10.1016/j.jpowsour.2018.12.013

[30] Hou, Y, Ouyang, Y, Pei, F, Hao, D. Voltage and Voltage Consistency Attenuation Law of the Fuel Cell Stack Based on the Durability Cycle Condition. SAE Technical Paper 2019; 2019-01-0386, DOI: 10.4271/2019-010386

[31] Zhoung, D, Lin, R, Jiang, Z, Zhu, Y, Liu, D, Cai, X, Chen, L. Low temperature durability and consistency analysis of proton exchange membrane fuel cell stack based on comprehensive characterization. Applied Energy 2020; 264: 114626, DOI: 10.1016/j.apenergy.2020.114626 